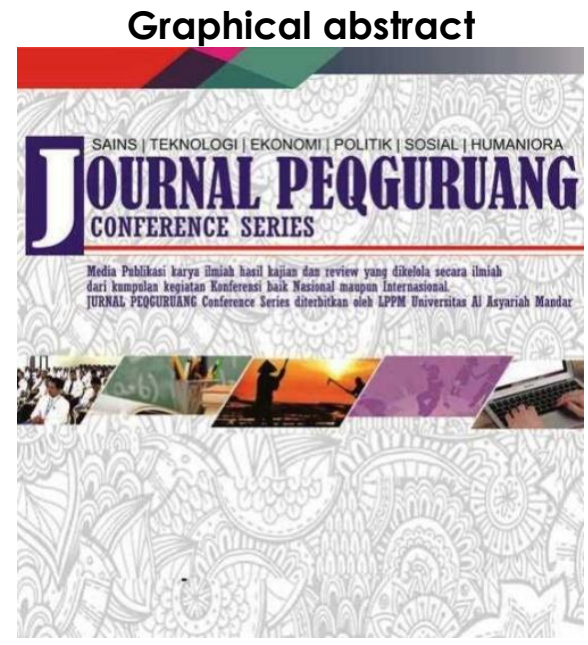

\title{
DAMPAK LIMBAH PABRIK KELAPA SAWIT TERHADAP KELESTARIAN LINGKUNGAN HIDUP DI KECAMATAN SARUDU KABUPATEN PASANGKAYU
}

${ }^{1}$ Irwan $\mathrm{K}^{*}$, ${ }^{1}$ Syamsu Alam, ${ }^{1}$ Ade Rahayu

Program Studi PPKn Fakultas Keguruan dan Ilmu Pendidikan Universitas Al Asyariah Mandar

${ }^{*}$ Corresponding author irwank786@gmail.com

Abstract

Impact of Palm Oil Mill Waste on Environmental Sustainability in Sarudu District, Pasangkayu Regency. This study was investigated in Sarudu Subdistrict, Pasangkayu Regency on the Impact of Palm Oil Mill Waste on environmental sustainability in Sarudu Subdistrict, Pasangkayu Regency. The issue stems from individual objections about the impact/smell of sewage in local residents' settlements which interferes with the activities of younger individuals and students during the learning process and pollutes the surrounding waterways. The examination was directed using an account research strategy with a subjective exploratory approach. The purpose of this study was to find out what the effect of wastage of palm oil on the carrying capacity of nature in the Sarudu area of the Pasangkayu Regime. This examination uses perception techniques, meetings and documentation, with the number of witnesses as many as 4 people and 1 worker. As a result of the examination, it is known that the consequences of wasting oil palm on normal assets, residents, and settlements are pollution of rivers and individual wells, air pollution due to plant smoke, and noise. In fact, after the inspection, Alhamdulillah, there has been control of waste pollution in accordance with the Nature Law article 23 paragraph 2 of Law no. 32 of 2009.

Keywords: Waste Impact, Palm Oil, Environmental Sustainability
Abstrak

Dampak Limbah Pabrik Kelapa sawit Terhadap Kelestarian Lingkungan Hidup Di Kecamatan Sarudu Kabupaten Pasangkayu. Kajian ini diteliti di Kecamatan Sarudu, kabupaten Pasangkayu tentang Dampak Limbah pabrik kelapa sawit terhadap kelestarian lingkungan hidup dikecamatan sarudu kabuaten pasangkayu. Isu tersebut bermula dari adanya keberatan individu tentang dampak/bau busuk dari limbah di pemukiman penduduk setempat yang mengganggu aktivitas individu dan siswa yang lebih muda selama proses pembelajaran dan mengotori saluran air di sekitarnya. Pemeriksaan diarahkan menggunakan strategi penelitian akun dengan pendekatan eksplorasi subjektif. Tujuan penelitian ini adalah untuk mengetahui apa Pengaruh Pemborosan Tanaman Kelapa Sawit terhadap Daya Dukung Alam di Kawasan Sarudu Rezim Pasangkayu. Pemeriksaan ini menggunakan teknik persepsi, pertemuan dan dokumentasi, dengan jumlah saksi sebanyak 4 orang dan 1 orang pekerja. Akibat dari pemeriksaan tersebut diketahui bahwa akibat yang ditimbulkan oleh pemborosan kelapa sawit terhadap aset-aset normal, penduduk, dan pemukiman adalah pencemaran sungai dan air sumur individu, pencemaran udara karena asap tanaman, dan keributan. Padahal, setelah dilakukan pemeriksaan, Alhamdulillah sudah ada pengendalian pencemaran limbah sesuai UU Alam pasal 23 ayat 2 UU No. 32 tahun 2009.

Kata Kunci: Dampak Limbah, Kelapa Sawit, Kelestarian Lingkungan

Article history

DOI: https://dx.doi.org/10.35329/ip.v3i2.2420

Received : 07 Agustus 2021 | Received in revised form : 18 September 2021 | Accepted : 23 November 2021 


\section{PENDAHULUAN}

Lingkungan hidup adalah jumlah semua benda dan kondisi yang ada dalam ruang yang kita tempati yang mempengaruhi kehidupan kita. Istilah lingkungan hidup, dalam bahasa Inggris disebut dengan environment, dalam bahasa belanda milleu dan dalam bahasa prancis disebut dengan environment (M. Daud Silalahi, 2001). Manusia memanfaatkan bagian-bagian lingkungan hidup seperti hewan-hewan, tumbuh-tumbuhan, air, udara, sinar matahari, garam, kayu, barang-barang tambang dan lain sebagainya untuk keperluan hidup. Hewan dan binatang-binatang mikroba serta tumbuh-tumbuhan juga dapat hidup karena lingkungan hidupnya. Tumbuh-tumbuhan dapat hidup karena air, udara, humus, zat-zat hara dan sebagainya (Takdir Rahmadi, 2012). Perusahaan kelapa sawit mungkin merupakan bidang yang paling signifikan dalam kehidupan atau pengelolaan kabupaten. Secara luas berbicara, organisasi kelapa sawit dapat memperkenalkan pembukaan kerja yang menyinggung kehidupan individu, seperti mata air gaji negara (Fauzi, 2002).

Perusahaan kelapa sawit sangat penting untuk membayar daerah setempat. Sehingga sebagaimana ditunjukkan oleh Undang-Undang Nomor 5 Tahun 1984 pasal 3 yang menyatakan bahwa alasan majunya perusahaan kelapa sawit adalah untuk lebih mengembangkan kehidupan individu menjadi wajar dan sejahtera dengan memanfaatkan aset normal atau item pembangunan dan berfokus pada keseimbangan dan pemeliharaan. kehidupan. Meski demikian, keberadaan kawasan modern ini umumnya tidak berdampak positif, namun sebaliknya berdampak pada kawasan lokal yang ada di sekitarnya. Area modern yang sangat tunduk pada aset ekologis dapat menyebabkan pencemaran limbah di sekitar pabrik.

Pemborosan kelapa sawit adalah akumulasi dari peternakan kelapa sawit yang dikecualikan dari barang pokok atau merupakan hasil pengolahan kelapa sawit. Berdasarkan tempat pembentukan limbah kelapa sawit dapat digolongkan menjadi dua jenis yaitu limbah perkebunan kelapa sawit dan limbah insdutri kelapa sawit. Limbah kelapa sawit adalah sisa hasil tanaman kelapa sawit yang tidak termasuk dalam produk utama atau merupakan hasil ikutan dari pengolahan kelapa sawit. Berdasarkan tempat pembentukan limbah kelapa sawit dapat digolongkan menjadi dua jenis yaitu limbah perkebunan kelapa sawit dan limbah insdutri kelapa sawit (Eko, 2013).

Secara umum, pemborosan dari pabrik kelapa sawit terdiri dari tiga jenis, yaitu pemborosan cairan, pemborosan kuat dan pemborosan gas. Pencernaan pabrik kelapa sawit berasal dari unit interaksi pengukusan (sanitasi), siklus penjelasan dan pelepasan dari hidrosiklon. Pada umumnya penyalahgunaan cairan industri kelapa sawit mengandung bahan alam yang tinggi sehingga berpotensi mencemari air tanah dan badan air. Sementara itu, limbah padat dari pabrik kelapa sawit dirangkai menjadi dua, yaitu pemborosan mulai dari interaksi penanganan dan mulai dari basis penyiapan limbah cair. Limbah kuat yang dimulai dari siklus penanganannya adalah sebagai cap kelapa sawit yang tidak terisi, cangkang atau cangkang, helai atau filamen, slop atau lumpur, dan cake. Ladang kelapa sawit yang kosong dan cairan yang tidak diolah menyebabkan bau busuk, tempat yang cocok untuk lalat serangga dan kemungkinan untuk menghasilkan air lindi. Limbah padat yang berawal dari penanganan limbah cair adalah sebagai lumpur aktif yang digerakkan oleh akibat dari pengolahan air limbah. Untuk sementara, gas buang berasal dari proses perombakan senyawa anaerobik yang menghasilkan biogas, (Santoso, 2013)

PT. Awana Sawit Lestari adalah organisasi yang bergerak di bidang perkebunan kelapa sawit dan organisasi penanganan kelapa sawit yang terletak di Desa Sarudu, Kecamatan Sarudu, Rezim Pasangkayu. Petunjuk langkah demi langkah untuk menangani organisasi kelapa sawit harus memiliki efek dari pemborosan kelapa sawit. Efek dari penanganan tanaman meliputi: endapan dari ciptaan yang dapat menyebabkan kerusakan ekologis di pemukiman penghuni, saluran air dan kebun.

Mengingat landasan yang disusun oleh pencipta, pencipta tertarik untuk menyelidiki Pengaruh Pemborosan Tanaman Kelapa Sawit terhadap Daya Dukung Alam di Lokal Sarudu, Rezim Pasangkayu.

\section{METODE PENELITIAN}

Jenis penelitian yang digunakan adalah penelitian kualitatif yang bersifat naratif yang dicermati dari Dampak Limbah Pabrik Kelapa Sawit terhadap Kelestarian Lingkungan Hidup Dikecamatan Sarudu Kabupaten Pasangkayu. Menurut Maleong, teknik subjektif adalah pemeriksaan logis yang berencana untuk memahami realitas dalam kontak sosial yang normal dengan berfokus pada siklus hubungan korespondensi yang mendalam antara ilmuwan dan keajaiban yang sedang diselidiki.Berdasarkan penerangan diatas, maka pada penelitian ini peneliti bermaksud untuk mengungkapkan apa Dampak Limbah Pabrik Kelapa Sawit Terhadap Kelestarian Lingkungan Hidup Dikecamatan Sarudu Kabupaten Pasangkayu.

Penlitian ini dilkukan mulai bulan Oktober 2019 sampai mret 2021. Kegitan penlitian ini dilaksanakan di kelurahan Sarudu Kabupaten Pasangkayu.

Populasi dalam penelitian ini adalah warga masyarakat yang terdampak limbah pabrik kelapa sawit yang bermukim sekitar pabrik tersebut. Sedangkan yang terpilih sebagai sampel dari populasi adalah warga masyarakat Desa Sarudu, Tokoh Masyarakat, Petani Kelapa Sawit. 
Titik fokus eksplorasi bersifat spekulatif sesuai dengan kemajuan penelitian (Meleong, 2004 : 237) menyatakan bahwa aksentuasi eksplorasi direncanakan untuk membatasi informasi subjektif, seperti halnya membatasi eksplorasi untuk memutuskan informasi yang besar dan dapat diterapkan. Dalam pemeriksaan ini, penelitian memfokuskan mengenai Dampak Limbah Kelapa Sawit Terhadap Sumber Daya Alam, Penduduk, \& Permukiman

\section{Instrumen Penelitian}

(Arikunto, 2002 : 136), menyatakan bahwa instrumen eksplorasi adalah perangkat atau perkantoran yang digunakan oleh tenaga ahli dalam mengumpulkan informasi sehingga pekerjaannya lebih sederhana dan hasilnya lebih baik, karena lebih tepat, total, dan presisi sehingga lebih mudah diukur. Mengingat tata cara pengumpulan informasi yang digunakan, instrumen eksplorasi ini menggunakan pedoman rapat dan kontrol survei, seperti halnya pengelolaan dokumentasi.

\section{Teknik Pengumpulan Data}

1. Persepsi

Persepsi adalah serangkaian latihan yang diselesaikan oleh analis pada suatu interaksi atau artikel yang menggunakan titik pemahaman informasi yang bergantung pada keajaiban atau kondisi yang bergantung pada informasi atau pemikiran yang baru diketahui. Akibatnya, persepsi yang dibuat oleh pencipta adalah melalui persepsi langsung di daerah pemeriksaan di Kota Sarudu, Wilayah Sarudu, Aturan Pasangkayu, khususnya daerah setempat yang dipengaruhi oleh Pemborosan Pabrik Kelapa Sawit.

2. Pertemuan

Rapat adalah pengumpulan informasi dengan mengajukan pertanyaan secara langsung kepada responden. Dengan teknik ini, pencipta berusaha mengumpulkan informasi dengan menanyakan responden atau data. Struktur yang digunakan adalah pertemuan yang telah diatur sebelumnya oleh pencipta yang difokuskan pada saksi-saksi yang mempengaruhi eksplorasi ini. Individu yang ditemui adalah direktur pabrik kelapa sawit, 1 staf, 3 perwakilan dan lima penghuni yang terpengaruh oleh pemborosan pabrik kelapa sawit.

3. Dokumentasi

Dalam investigasi ini, analis mencari informasi tentang hal-hal atau faktor-faktor yang berasal dari sumber-sumber yang diturunkan, misalnya, catatan sejarah, buku, majalah, makalah, dll. Jadi pencipta menggunakan strategi naratif sebagai informasi dimulai seperti yang ditunjukkan oleh dokumen yang terkandung di pabrik kelapa sawit.

\section{Teknik Analisis Data}

Analisis data ialah penelaahan dan penguraian data hingga menghasilkan simpulan yang didapat dari hasil wawancara, observasi, dan dokumentasi, dan yang akan dipertimbangkan, membuat tujuan sehingga mudah dipahami tanpa orang lain, model informasi dalam investigasi ini mengikuti ide-ide yang diberikan oleh Miles dan Humberman.

(Miles dan Hubermen, 2007 : 139-140) mengungkap bahwa latihan dalam pemeriksaan informasi subjektif dilakukan secara cerdas dan terjadi tanpa henti pada setiap tahap eksplorasi sehingga selesai.

1. Pengenalan Informasi

Dengan menunjukkan atau memperkenalkan informasi, akan lebih jelas apa yang terjadi selama pemeriksaan. Setelah itu penting untuk memiliki rencana kerja yang bergantung pada apa yang telah dipersepsikan.

Dalam mengenalkan informasi, selain memanfaatkan teks cerita, juga bisa dalam bahasa nonverbal seperti garis besar, denah, jaringan, dan tabel. Pengenalan informasi adalah cara untuk mengumpulkan data yang dikoordinasikan oleh kelas atau pengelompokan berdasarkan kasus per kasus. Ujian subyektif dalam memperkenalkan informasi harus dimungkinkan seperti penggambaran singkat, grafik, hubungan antar kelas, diagram alir dan semacamnya. Seperti yang dijelaskan oleh Sugiyono, "yang biasa digunakan untuk memperkenalkan informasi dalam ujian subjektif adalah teks akun”. (Sugiyono, 2007: 249).

\section{Sajian data}

Dari hasil penelitian informasi yang peneliti dapatkan mengenai pembelajaran daring begitu banyak karena dapat ikut berpartisipasi pada saat pembelajaran berlangsung. Informasi yang memberikan gambaran begitu jelas dan memudahkan peneliti untuk dapat menganalisis dari hasil penelitian.(Sugiyono, 2007: 247).

3. Penarikan Kesimpulan

Dari hasil reduksi data, sajian data maka peneliti melakukan penarikan kesimpulan mengenai pembelajaran daring ini. Maka jika hasil temuan yang telah didapatkan didukung oleh bukti yang kuat dan jelas ketika pengumpulan informasi maka dari itu tujuan yang dihasilkan tujuan yang dapat diandalkan.

\section{HASIL DAN PEMBAHASAN}

Salah satu dampak negatif yang muncul dari keberadaan Pabrik Kelapa Sawit Terhadap sumber daya alam salah satunya adalah pencemaran sungai akibat pihak perusahan membuang limbahnya ke sungai tanpa mengetahui zat-zat yang terkandung di dalam limbah tersebut padahal limbahnya mengandung bahan berbahaya dan beracun.

Salah satu akibat buruk yang muncul dari keberadaan Pabrik Kelapa Sawit adalah pemborosan fasilitas industri yang dapat mempengaruhi kesehatan lingkungan sekitar jalur produksi, seperti limbah yang sudah jadi, asap pabrik pengolahan, keributan, dll. Mengingat efek sampingnya. Dari eksplorasi dan pertemuan dengan masyarakat setempat, dilacak bahwa efek pencemaran ekologis asli karena Limbah Olahan Kelapa Sawit seperti Kemasan Produk Organik Kosong, Kerang/Kerang, Helai/Filamen, Slop/Lumpur, dan Kue yang tidak diambil perawatan yang tepat dapat 
menyebabkan bau busuk yang mengerikan, tempat menetap bagi lalat. Selain itu, mungkin dapat memberikan lindi. Kemudian, yang kedua adalah asap tanaman yang mengotori Permukiman Penghuni menyebabkan pencemaran udara dan membuat bagian udara yang tidak diinginkan mengingat jarak antara jalur produksi dan lingkungan sangat dekat, sehingga asap dari fasilitas industri saluran menyebabkan pencemaran udara di sekitarnya. dan yang ketiga Kebisingan yang disebabkan dari perusahan kelapa sawit ketika melakukan proses pengolahan menjadi minyak hal ini meresahkan warga akibat kebisingan apa lagi di malam menyebabkan gangguan tidur.

Salah satu akibat buruk yang muncul dari keberadaan Pabrik Kelapa Sawit adalah tercemarnya pada area permukiman warga seperti pencemaran lingkungan, pencemaran air, dan pencemaran udara. Berdasarkan wawancara bersama warga pencemaran yang di lakukan perusahaan kelapa sawit terhadap permukiman warga yaitu air sumurnya hitam di sebabkan perusahaan membuang limbah cairnya ke are permukiman sehingga dapat merusak air tanah dan badan air serta pencemaran udara yang ditimbulkan oleh asap fasilitas industri. Dalam ilmu klinis, pencemaran udara mempengaruhi kesehatan termasuk masalah saluran pernapasan, penyakit jantung, penyakit berbagai organ tubuh, masalah konsepsi dan (hipertensi).

Hasil menyelidiki upaya penanggulangan pencemaran oleh perusahaan kelapa sawit menurut Hukum Lingkungan Hidup di lokasi penelitian di dapatkan terjadinya pencemaran terhadap kelestarian sumber daya alam akibat pihak perusahaan membuang limbahnya ke sungai tanpa mengetahui apa efek yang di timbulkan limbah tersebut. Kemudian limbah juga mencemari permukiman penduduk seperti limbah olahan yang tidak tertangani dengan baik sehingga menimbulkan bau busuk, asap pabrik menyebabkan polusi udara dan membuat komposisi udara menjadi tidak sehat karena Jarak pabrik dengan pemukiman penduduk sangat dekat, serta juga mencemari sumursumur warga sehingga air tersebut hitam.

\section{SIMPULAN}

Berdasrkan hasil pembhasan di atas mengnai Dampak Limbh Pabrik Kelpa Sawit Teradap Kelestarian Linkungan Hidup di Kecamtan Sarudu Kabupten Pasangkayu maka dapat di simpulkan bahwa limbah kelapa sawit sangat membawah dampak buruk khususnya di kecamatan sarudu karna dapat mencemari terhadap sumber daya alam seperti sungai mulai tercemari akibat limbah kelapa sawit ketika pihak perusahaan membuang limbahnya kesungai tanpa menyadari zat-zat yang terkandung dalam sampah meskipun sampah tersebut mengandung bahan berbahaya dan berbahaya dan selanjutnya mencemari wilayah penduduk, misalnya sampah yang tidak diolah dengan baik sehingga menimbulkan bau yang tidak sedap, tempat bersarangnya serangga dan lalat.kebisingan ketika pihak perusahaan melakukan pengolahan minyak sehingga hal ini meresahkan warga akibat kebisingan apa lagi dimalam hari menyebabkan gangguan tidur. Serta juga mencemari area permukiman seperti air sumurnya hitam di sebabkan perusahaan membuang limbah cairnya ke are permukiman sehingga dapat merusak air tanah dan badan air serta pencemaran udara yang ditimbulkan oleh asap tanaman. Dalam ilmu klinis, pencemaran udara mempengaruhi kesehatan termasuk masalah pernapasan, penyakit jantung, pertumbuhan ganas berbagai organ tubuh, masalah konsepsi dan (hipertensi).

\section{DAFTAR PUSTAKA}

Moleong. (2004) Metodologi Penelitian Kualitatif. Bandung : Remaja Rosdakarta, 237.

Arikunto, (2002) Instrumen Penelitian. Bandung : PT Rosda, 136.

Miles, Mattew B dan Amichael Huberman. (2007). Analisis Data Kualitatif Buku Sumber tentang Metode Baru. Terjemahan Tjetjep Rohendi Rohisi. Jakarta: Universitas Indonesia.

Sugiyono. (2007). Metode Penelitian Kuantitatif Kualitatif dan $R \& D$. Bandung: Alfabeta, 249.

Fauzi, (2002) Kelapa sawit, Budidaya Pemanfaatan Hasil dan Limbah, Analisis Usaha dan Pemasaran..Jakarta.Penerbit Swadaya.

Eko, (2013) Priyanto. Limbah Pabrik Kelapa Sawit.. Sumber : [online] tersedia: http://snkn1.blogspot.com/2013/05/limbah-pabrik-kelapasawit-pks.html.

Santoso, (2013) Avit. Manfaat Limbah Kelapa Sawit.. [online] Tersedia http://keripikkampus.blogspot.com/2013/02/manfaatlimbah-kelapa-sawit.html

Sudjana, (2010). Media Pembelajaran. Bandung: Sinar Baru Algensido.

M. Daud Silalahi, (2001). Hukum Lingkungan Dalam Sistem Penegakan Hukum Lingkungan Indonesia.

Takdir Rahmadi, (2012). Hukum Lingkungan di Indonesia. Jakarta. Penerbit PT Raja Grafindo Persada. 